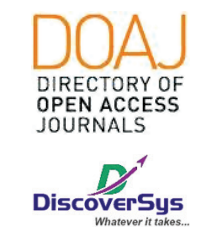

Published by DiscoverSys

\section{Hubungan antara kadar albumin dengan penyembuhan luka pada pasien pasca bedah di Rumah Sakit Umum Pusat Sanglah Denpasar}

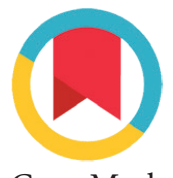

CrossMark

\author{
Ni Luh Gede Apsari Pararesthi, ${ }^{*}$ Kadek Agus Heryana Putra, ${ }^{2}$ Putu Kurniyanta ${ }^{2}$
}

\section{ABSTRACT}

Introduction: Wound healing is influenced by various factors, one of which is nutritional status. Nutritional status itself is often detected by one of the important signs of serum albumin. Albumin is a protein in human plasma that is soluble in water and high in concentration in blood plasma. Low albumin levels as an estimate of the causes of malnutrition and also associated with increased complications and postoperative death. Serum albumin less than $3.5 \mathrm{~g} / \mathrm{dL}$ is recognized by the patient as hypoalbuminemia.

Methods: This research was conducted with the aim of analyzing the relationship between albumin levels and wound healing in postoperative patients. This study used a cross sectional observational analytic method by taking secondary data from medical records of postoperative patients (disgestif surgery, neurosurgery, orthopedic surgery, oncology surgery) at Sanglah General Hospital.

Result: Of the 60 patients involved in this study, patients with abnormal albumin levels were $36.7 \%$ and patients with normal albumin levels were $63.3 \%$. The chi-square test results showed that postoperative patients who had the last abnormal albumin level before surgery 5.1 times more with unrecover wound compared to patients with normal albumin levels $(\mathrm{PR}=5.182 ; 95 \% \mathrm{Cl}=2.181-12.310, \mathrm{p}=$ 0.00001).

Conclusion: There is a significant relationship between albumin levels and wound healing.
1Program Studi Pendidikan Dokter ${ }^{2}$ Departemen/SMF IImu Anestesi dan Terapi Intensif RSUP Sanglah Fakultas Kedokteran Universitas Udayana

*Korespondensi:

Ni Luh Gede Apsari Pararesthi, Program Studi Pendidikan Dokter Fakultas Kedokteran Universitas Udayana apsaripararesthi@gmail.com

Diterima: 19-03-2019

Disetujui: 21-11-2019

Diterbitkan: 01-12-2019

Keywords: albumin levels, wound healing

Cite This Article: Pararesthi, N.L.G.A., Putra, K.A.H., Kurniyanta, P. 2019. Hubungan antara kadar albumin dengan penyembuhan luka pada pasien pasca bedah di Rumah Sakit Umum Pusat Sanglah Denpasar. Intisari Sains Medis 10(3): 759-765. D0I: 10.15562/ism.v10i3.450

\title{
ABSTRAK
}

Latar Belakang: Penyembuhan luka dipengaruhi oleh berbagai faktor, salah satunya adalah faktor status nutrisi. Status nutrisi sendiri sering dideteksi oleh salah satu tanda penting yaitu serum albumin. Albumin merupakan protein dalam plasma manusia yang larut dalam air dan tinggi konsentrasinya dalam plasma darah. Kadar albumin yang rendah sebagai perkiraan penyebab malnutrisi dan juga berhubungan dengan peningkatan komplikasi serta kematian postoperasi. Serum albumin yang kurang dari $3.5 \mathrm{~g} / \mathrm{dL}$ diakui pasien tersebut hipoalbuminemia.

Metode: Penelitian ini dilaksanakan dengan tujuan untuk menganalisis hubungan kadar albumin dengan penyembuhan luka pada pasien pasca bedah. Penelitian ini menggunakan metode observasional analitik cross sectional dengan mengambil data sekunder dari rekam medis pasien pasca bedah (bedah disgestif, bedah saraf, bedah ortopedi, bedah onkologi) di RSUP Sanglah.

Hasil: Dari 60 pasien yang terlibat dalam penelitian ini didapatkan pasien dengan kadar albumin tidak normal sebesar $36.7 \%$ dan pasien dengan kadar albumin normal sebanyak 63.3\%. Hasil uji chi-square menunjukkan bahwa pasien pasca bedah yang sebelum operasi memilki kadar albumin terakhir tidak normal 5.1 kali lebih banyak mengalami luka tidak sembuh dibanding pasien dengan kadar albumin normal ( $P R=5.182 ; 95 \% \mathrm{Cl}=2.181-12.310, \mathrm{p}=0.00001)$.

Simpulan: Terdapat hubungan yang signifikan antara kadar albumin dengan penyembuhan luka.

Kata kunci: kadar albumin, penyembuhan luka

Cite Pasal Ini: Pararesthi, N.L.G.A., Putra, K.A.H., Kurniyanta, P. 2019. Hubungan antara kadar albumin dengan penyembuhan luka pada pasien pasca bedah di Rumah Sakit Umum Pusat Sanglah Denpasar. Intisari Sains Medis 10(3): 759-765. D0I: 10.15562/ism.v10i3.450

\section{PENDAHULUAN}

World Health Organization (WHO) menyatakan bahwa kasus bedah merupakan masalah kesehatan masyarakat. Setidaknya diperkirakan bahwa $11 \%$ dari beban penyakit di dunia berasal dari penyakit atau keadaan yang sebenarnya bisa ditanggulangi dengan melakukan tindakan pembedahan. ${ }^{1}$

Penelitian yang dilakukan di 56 negara dari 192 negara anggota WHO pada tahun 2004 
diperkirakan bahwa sebanyak 234,2 juta prosedur pembedahan dilakukan setiap tahun yang mana berpotensi terhadap komplikasi dan kematian. ${ }^{2}$ Pembedahan sendiri merupakan suatu tindakan pengobatan yang menggunakan cara invasif dengan cara membuka atau menampilkan bagian tubuh yang akan ditangani melalui sayatan yang diakhiri dengan penutupan dan penjahitan luka, di mana pada masa setelah operasi terjadi suatu fase metabolisme baik anabolisme maupun katabolisme. ${ }^{3}$

Pelayanan bedah merupakan pelayanan di rumah sakit yang sering menimbulkan cidera medis dan komplikasi yang dapat membahayakan nyawa. ${ }^{4}$ Sayatan atau luka yang dihasilkan merupakan suatu trauma bagi penderita dan bisa menimbulkan berbagai keluhan dan gejala bisa berupa nyeri. Nyeri merupakan suatu sensori subjektif dan pengalaman emosional tidak menyenangkan berkaitan dengan kerusakan jaringan yang aktual atau potensial. ${ }^{2}$

Akibat lain yang dapat timbul dari tindakan pembedahan yang paling sering adalah malnutrisi. Secara fisiologis, penurunan status gizi disebabkan oleh terjadinya stres fisiologis terhadap pembedahan, yaitu terjadinya hipermetabolisme dan katabolisme. Selama pembedahan, basal metabolism rate (BMR) dan produksi glukosa hepatik meningkat. ${ }^{5}$

Khusus pada pasien perioperatif, prevalensi malnutrisi ditemukan hingga sebesar 34.5\%. Salah satu komplikasi pasca pembedahan yang dapat timbul akibat malnutrisi adalah penyembuhan luka bekas operasi yang tidak baik. Zat gizi yang memiliki peranan salah satunya adalah protein. Protein memiliki peran sangat penting pada seluruh proses atau fase penyembuhan luka. Pasien trauma/bedah membutuhkan asupan protein yang lebih banyak. Jika pasien telah mengalami malnutrisi protein, maka akan berdampak pada penyembuhan luka. Parameter kadar protein yang digunakan adalah kadar albumin yang telah banyak digunakan sebagai salah satu skrining pra pembedahan. Menurunnya kadar albumin serum disebut dengan hipoalbuminemia. Keadaan hipoalbuminemia dapat menyebabkan kelainan berupa komplikasi dari penyakit yang diderita sebelumnya sehingga berakibat pada tingkat morbiditas dan mortalitas pasien. ${ }^{5}$

\section{METODE}

Penelitian ini menggunakan metode observasional analitik cross sectional, dilaksanakan dilaksanakan di Rumah Sakit Umum Pusat (RSUP) Sanglah, Denpasar, Bali pada bulan Februari 2018 sampai dengan Desember 2018. Sampel penelitian adalah pasien pasca bedah yang tercatat rekam medisnya dan menjadi pasien yang dirawat di Rumah Sakit Umum Pusat Sanglah, Denpasar yang memenuhi kriteria inklusi dan eksklusi. Kriteria inklusi adalah Pasien pasca bedah yang terdata dalam rekam medis di Rumah Sakit Umum Pusat Sanglah, Denpasar. Rekam medis tersebut memuat data mengenai kadar albumin dan penyembuhan luka pada pasien pasca bedah. Kriteria eksklusi adalah data rekam medis pasien pasca bedah di Poli Rumah Sakit Umum Pusat Sanglah, Denpasar yang tidak lengkap (tidak ada data mengenai kadar albumin dan penyembuhan luka pasien pasca bedah), pasien yang meminta pulang paksa selama perawatan atau pasien yang meninggal selama perawatan dan pasien dengan usia dibawah 20 tahun dan diatas 80 tahun. Sampel diambil dengan teknik consecutive sampling yaitu dengan memilih sampel secara sengaja (non-probability) berdasarkan kriteria inklusi dan eksklusi hingga jumlah 60 sampel minimal terpenuhi.

Penelitian ini menggunakan menggunakan data sekunder dari rekam medis pasien. Data sekunder rekam medis pasien berupa kadar albumin, penyembuhan luka, usia, jenis kelamin, dan jenis pembedahan digunakan dalam penelitian ini. Data kadar albumin dikategorikan menjadi normal (3,5-5,0 g/dL) dan tidak normal (<3,5 g/dL). Sementara data penyembuhan luka dikategorikan menjadi sembuh (3 kriteria penyembuhan luka terpenuhi) dan tidak sembuh (salah satu kriteria penyembuhan luka tidak terpenuhi).

Data-data yang telah dikumpulkan dan dikategorikan kemudian dianalisis menggunakan perangkat lunak IBM SPSS Statistik versi 24. Analisis data yang digunakan untuk mengetahui hubungan antara kadar albumin sebagai variabel bebas dengan penyembuhan luka sebagai variabel terikat adalah uji komparatif non-parametris untuk dua kelompok independen yaitu kai-kuadrat (Chi-Square test) dengan menggunakan derajat kemaknaan $\alpha=0.05$ dan derajat kepercayaan $=$ 95\%. Fisher exact test digunakan sebagai alternatif apabila hasil analisis kai-kuadrat memiliki nilai expected count $<5$ sebesar lebih dari $20 \%$. Apabila nilai $\mathrm{p} \leq 0,05$, maka hipotesis nol ditolak dan hipotesis alternatif diterima. Apabila nilai $\mathrm{p} \geq 0,05$ maka hipotesis nol yang diterima.

\section{HASIL}

Jumlah total pasien pasca bedah periode Oktober 2017 hingga November 2017 yang telah memenuhi kriteria inkulsi untuk terlibat dalam penelitian ini sebanyak 60 orang. Karakteristik subyek dalam penelitian ini meliputi jenis kelamin, usia, dan jenis pembedahan dapat dilihat pada Tabel 1 .

38 subyek $(63,3 \%)$ memilki kadar albumin yang normal dan untuk distribusi kadar albumin yang tidak normal terdapat pada 22 subyek (36,7\%). 
Tabel 1 Karakteristik Umum Subyek Penelitian

\begin{tabular}{lcc}
\hline Karakteristik & Jumlah & (\%) \\
\hline Jenis Kelamin & 19 & 31.7 \\
$\quad$ Laki-laki & 41 & 68.3 \\
$\quad$ Perempuan & & \\
Usia (tahun) & 42 & 70.0 \\
$\quad$ Dewasa 18-59 tahun & 18 & 30.0 \\
$\quad$ Usia lanjut $>59$ tahun & & \\
Jenis Pembedahan & 24 & 40.0 \\
$\quad$ Bedah digestif & 2 & 3.3 \\
Bedah saraf & 14 & 23.3 \\
Bedah ortopedi & 20 & 33.3 \\
Bedah onkologi & &
\end{tabular}

Tabel 2 Distribusi Frekuensi Variabel Penelitian

\begin{tabular}{lcc}
\hline Variabel & Jumlah & $\%$ \\
\hline Kadar Abumin & 38 & \\
$\quad$ Normal & 22 & 63.3 \\
$\quad$ Tidak normal & & 36.7 \\
Penyembuhan Luka & 40 & \\
$\quad$ Sembuh & 20 & 66.7 \\
$\quad$ Tidak sembuh & & 33.3 \\
\hline
\end{tabular}

Tabel 3 Karakteristik Subyek berdasarkan Kadar Albumin

\begin{tabular}{|c|c|c|c|c|c|}
\hline \multirow[b]{3}{*}{ Variabel } & \multicolumn{4}{|c|}{ Kadar Albumin } & \multirow[b]{3}{*}{$\mathbf{p}$} \\
\hline & \multicolumn{2}{|c|}{ Normal } & \multicolumn{2}{|c|}{ Tidak normal } & \\
\hline & Jumlah & $\%$ & Jumlah & $\%$ & \\
\hline \multicolumn{6}{|l|}{ Jenis kelamin ${ }^{a}$} \\
\hline Laki-laki & 8 & 42,1 & 11 & 57,9 & \multirow{2}{*}{$0,020^{*}$} \\
\hline Perempuan & 30 & 73,2 & 11 & 26,8 & \\
\hline \multicolumn{6}{|l|}{ Usia $^{a}$} \\
\hline Dewasa & 28 & 66,7 & 14 & 33,3 & \multirow{2}{*}{0,413} \\
\hline Usia lanjut & 10 & 55,6 & 8 & 44,4 & \\
\hline \multicolumn{6}{|l|}{ Jenis Pembedahan ${ }^{\mathrm{b}}$} \\
\hline Bedah digestif & 13 & 54,2 & 11 & 45,8 & \multirow{4}{*}{0,086} \\
\hline Bedah saraf & 0 & 0 & 2 & 100 & \\
\hline Bedah ortopedi & 9 & 64,3 & 5 & 35,7 & \\
\hline Bedah onkologi & 16 & 80 & 4 & 20 & \\
\hline
\end{tabular}

${ }^{\mathrm{a}} \mathrm{p}$ (chi-square test)

${ }^{\mathrm{b}} \mathrm{p}$ (fisher exact test)

${ }^{*}=$ bermakna $(\mathrm{p}<0.05)$ penyembuhan luka ditemukan dalam kateogri tidak sembuh (Tabel 2).

Berdasarkan tabel 3, 11 suyek laki-laki (57,9\%) dan 11 subyek perempuan $(26,8 \%)$ yang memilki kadar albumin tidak normal $(<3,5 \mathrm{~g} / \mathrm{dL})$. Hasil uji statistik chi square menunjukkan adanya hubungan yang bermakna antara jenis kelamin dan kadar albumin $(\mathrm{p}=0,020)$. Bila dilihat dari karakteristik usia proporsi subyek berusia lanjut yang memilki kadar albumin tidak normal adalah sebanyak $44,4 \%$, angka ini lebih tinggi disbanding dengan proporsi subyek dewasa yang memilki kadar albumin tidak normal yaitu sebanyak 33,3\%. Berdasarkan jenis pembedahan yang dijalani pasien proporsi pasien bedah digestif yang memilki kadar albumin tidak normal adalah sebanyak 11 subyek $(45,8 \%)$, pada pasien bedah saraf sebanyak 2 subyek (100\%) memilki albumin tidak normal, sedangkan proporsi kadar albumin tidak normal pada bedah ortopedi dan bedah onkologi adalah $35,7 \%$ dan $20 \%$. Hasil uji statistik chi square menunjukkan tidak adanya hubungan bermakna antara usia terhadap kadar albumin sebelum operasi dan hasil uji statistik fisher exact juga menunjukkan tidak adanya hubungan yang bermakna jenis pembedahan terhadap kadar albumin sebelum operasi.

Pada tabel 4 dapat dilihat karakteristik suyek penelitian berdasarkan penyembuhan luka pasien pada hari ke-3. 12 subyek laki-laki $(63,2 \%)$ dan 8 subyek perempuan $(19,5 \%)$ mengalami luka pasca operasi yang tidak sembuh. Hasil analisis bivariat dengan chi square menunjukkan adanya hubungan yang signifikan antara jenis kelamin dengan penyembuhan luka $(\mathrm{p}=0,001)$. Berdasarkan karakteristik usia terdapat 12 subyek dewasa $(28,6 \%)$ dan 8 subyek berusia lanjut $(44,4 \%)$ yang mengalami luka operasi yang tidak sembuh. Hasil uji stastistik chi square menunjukkan tidak adanya hubungan yang bermakna antara usia dengan penyembuhan luka pasien pasca bedah. Dilihat dari karakteristik jenis pembedahan terdapat sebanyak 11 subjek $(45,8 \%)$ pasien bedah digestif dan 2 subyek (100\%) pasien bedah saraf yang mengalami luka pasca operasi tidak sembuh. Proposi luka pasca operasi yang tidak sembuh pada pasien bedah ortopedi dan bedah onkologi adalah sebanyak 35,7\% dan 10\%. Hasil uji statistic fisher exact menunjukkan bahwa ada hubungan yang bermakna antara jenis pembedahan dengan penyembuhan luka pada pasien pasca bedah $(\mathrm{p}=0,009)$.

Subyek yang memilki kadar albumin tidak normal memilki proporsi yang lebih tinggi terhadap kejadian luka yang tidak sembuh sebanyak $68,2 \%$ dibandingkan dengan luka sembuh sebanyak 31,8\%. Sementara, pada subyek penelitian yang memilki kadar albumin normal proporsi terhadap kejadian luka tidak sembuh jauh lebih 
Tabel 4 Karakteristik Subyek berdasarkan Penyembuhan Luka

\begin{tabular}{|c|c|c|c|c|c|}
\hline \multirow[b]{3}{*}{ Variabel } & \multicolumn{4}{|c|}{ Penyembuhan Luka } & \multirow[b]{3}{*}{$\mathbf{p}$} \\
\hline & \multicolumn{2}{|c|}{ Sembuh } & \multicolumn{2}{|c|}{ Tidak sembuh } & \\
\hline & Jumlah & $\%$ & Jumlah & $\%$ & \\
\hline \multicolumn{6}{|l|}{ Jenis kelamin ${ }^{a}$} \\
\hline Laki-laki & 7 & 36,8 & 12 & 63,2 & \multirow{2}{*}{$0,001^{*}$} \\
\hline Perempuan & 33 & 80,5 & 8 & 19,5 & \\
\hline \multicolumn{6}{|l|}{ Usia $^{a}$} \\
\hline Dewasa & 30 & 71,4 & 12 & 28,6 & \multirow{2}{*}{0,232} \\
\hline Usia lanjut & 10 & 55,6 & 8 & 44,4 & \\
\hline \multicolumn{6}{|l|}{ Jenis Pembedahan ${ }^{\mathrm{b}}$} \\
\hline Bedah digestif & 13 & 54,2 & 11 & 45,8 & \multirow{4}{*}{$0,009^{*}$} \\
\hline Bedah saraf & 0 & 0 & 2 & 100 & \\
\hline Bedah ortopedi & 9 & 64,3 & 5 & 35,7 & \\
\hline Bedah onkologi & 18 & 90 & 2 & 10 & \\
\hline
\end{tabular}

${ }^{\mathrm{a}} \mathrm{p}$ (chi-square test)

${ }^{\mathrm{b}} \mathrm{p}$ (fisher exact test)

${ }^{*}=$ bermakna $\mathrm{p}<0.05$ )

Tabel 5 Hasil Analisis Bivariat Kadar Albumin dengan Penyembuhan Luka

\begin{tabular}{|c|c|c|c|c|c|c|c|}
\hline \multirow{3}{*}{$\begin{array}{l}\text { Kadar } \\
\text { Albumin }\end{array}$} & \multicolumn{4}{|c|}{ Penyembuhan Luka } & \multirow{3}{*}{$\begin{array}{l}\text { Prevalensi } \\
\text { Rasio (PR) }\end{array}$} & \multirow{3}{*}{$\begin{array}{c}95 \% \\
\text { Confident } \\
\text { Interval } \\
\text { (CI) }\end{array}$} & \multirow[b]{3}{*}{ Nilai P } \\
\hline & \multicolumn{2}{|c|}{ Tidak Sembuh } & \multicolumn{2}{|c|}{ Sembuh } & & & \\
\hline & Jumlah & $\%$ & Jumlah & $\%$ & & & \\
\hline $\begin{array}{l}\text { Tidak } \\
\text { Normal }\end{array}$ & 15 & 68,2 & 7 & 31,8 & \multirow[t]{2}{*}{5,182} & \multirow{2}{*}{$\begin{array}{l}2,181- \\
12,310\end{array}$} & \multirow[t]{2}{*}{0,00001} \\
\hline Normal & 5 & 13,2 & 33 & 86,8 & & & \\
\hline
\end{tabular}

rendah $13,2 \%$ bila dibandingkan dengan luka sembuh sebanyak 86,8\% (Tabel 5). Hasil korelasi signifikansi antara variabel kadar albumin dengan variabel penyembuhan luka ditunjukkan dengan nilai Prevalensi Rasio (PR) pada tabel 5, yaitu 5,182 . Hal ini berarti bahwa subyek penelitian yang memilki kadar albumin tidak normal beresiko mengalami luka tidak sembuh 5,182 kali lebih besar dibandingkan dengan subyek yang memilki kadar albumin normal. Pada penelitian ini didapat nilai 95\% confident interval (CI) yaitu 2,181-12,310, dapat dikatakan hasil data pada sampel penelitian ini signifikan di populasi. Hasil uji statistik dengan menggunakan chi-square didapatkan nilai $p=0.00001$, ada hubungan signifikan antara kadar albumin dengan peneymbuhan luka pada pasein pasca bedah di RSUP Sanglah, Denpasar (Tabel 5).

\section{DISKUSI}

Penyembuhan luka dipengaruhi oleh berbagai faktor, salah satunya adalah faktor status nutrisi. Status nutrisi sendiri sering dideteksi oleh salah satu tanda penting yaitu serum albumin. Albumin merupakan protein dalam plasma manusia yang larut dalam air dan tinggi konsentrasinya dalam plasma darah. Pada penelitian ini didapatkan 36,7\% pasien memilki kadar albumin tidak normal sebelum operasi dan beresiko mengalami luka tidak sembuh. Angka ini lebih rendah dari penelitian yang dilakukan di Surakarta yang mendapatkan hasil $37,5 \%$ pasien memilki kadar albumin tidak normal sebelum operasidan beresiko mengalami luka tidak sembuh. ${ }^{6}$

Pada penelitian ini didapatkan hasil-hasil yang mendukung studi-studi sebelumnya bahwa kadar albumin berhubungan dengan penyembuhan luka pada pasien pasca bedah. Berdasarkan uji statistic Chi-Squareuntuk menganalisis hubungan antara kadar albumin dan penyembuhan luka didapatkan nilai $\mathrm{p}=0,00001$ yang berarti terdapat hubungan yang signifikan/bermakna antara kadar albumin dan penyembuhan luka.

Hasil penelitian ini sesuai dengan studi lain yang dilakukan di Makassar menunjukkan bahwa dari 4 responden yang kadar albuminnya abnormal sebagian besar lukanya tidak sembuh sebanyak 3 orang $(75,0 \%)$ sedangkan dari 29 responden yang kadar albuminnya normal semua lukanya sembuh sebanyak 29 orang (100,0\%). Berdasarkan uji Fisher Exact Test diperoleh nilai $\mathrm{p}=0,001$. Hasil penelitian tentang kadar albumin pasien post operasi laparatomi di Ruang Rawat Inap Rumah Sakit Tk II Pelamonia Makassar menunjukkan bahwa sebagian besar responden kadar albuminnya normal yakni sebanyak 29 orang $(87,9 \%)$. Hal ini disebabkan karena pada umumnya sebelum dilakukan tindakan operasi dilakukan upaya optimalisasi terhadap kadar albumin terlebih dahulu dengan pemberian albumin apabila kadar albuminnya rendah. ${ }^{7}$ Kadar albumin yang rendah sebagai perkiraan penyebab malnutrisi dan juga berhubungan dengan peningkatan komplikasi serta kematian postoperasi. Peran dari albumin pre operasi adalah sebagai prediksi dari outcome klinis pada pasien dengan pembedahan gastrointestinal. Setiap pasien sebelum operasi menjalani pemeriksaan kadar albumin pre operasi. Serum albumin yang kurang dari 3,5g/dL diakui pasien tersebut hipoalbuminemia. Pengukuran serum albumin preoperative dan level albumin digunakan untuk analisis data keadaan pasien. Serum albumin diambil pada hari terdekat operasi atau satu minggu sebelum operasi. ${ }^{7}$

Perbedaan penelitian ini dengan penelitian di Makassar yaitu pada penelitian ini menggunakan subyek pasca bedah dengan jenis pembedahan yang bervariasi (bedah digestif, bedah saraf, bedah ortopedi, dan bedan onkologi). Hal ini menyebabkan adanya hasil yang cenderung dominan pada bedah digestif dan bedah onkologi dimana pada kedua jenis bedah ini pengukuran albumin pra operasi 
lebih sering dilakukan sedangkan pada bedah saraf dan ortopedi RSUP Sanglah pengukuran albumin pra operasi jarang dilakukan. Berbeda dengan penelitian di Makassar yang hanya menggunakan satu jenis pembedahan yaitu bedah digestif (laparotomi) saja.

Pada penelitian yang dilakukan Taiwan yang berjudul "Clinical Impact of Albumin in Advanced Head and Neck Cancer Patients with Free Flap Reconstruction-Cohort Restropective Study" melibatkan 233 pasien dengan karakteristik klinis dari pasien yaitu rerata berusia 54 tahun (30-84 tahun). Populasi termasuk $220(94,4 \%)$ pasien laki-laki dan $13(5,6 \%)$ pasien perempuan. Tingkat albumin serum pra operasi rata-rata adalah 4,2 g/dL (2,5$5,8 \mathrm{~g} / \mathrm{dL})$. Rata-rata tingkat serum albumin pasca operasi adalah 3,1 g dL (1,9-4,3 g/dL). 53 pasien $(22,7 \%)$ memiliki diabetes mellitus tipe II dan 24 pasien (10,3\%) memiliki penyakit ginjal kronis. Hasil pada penelitian di Taiwan menunjukkan kadar albumin serum pasca operasi yang lebih rendah ( $\mathrm{p}<0,001)$ secara signifikan terkait dengan kemungkinan yang lebih tinggi dari infeksi luka pasca operasi mayor. Dari 233 pasien yang mengalami infeksi luka pasca operasi mayor adalah 60 orang. ${ }^{8}$

Perbedaannya dengan penelitian ini, penelitian di Taiwan menggunakan metode penelitian cohort retrospektif dimana pada penelitian cohort hasil penelitian dapat menjelaskan hubungan causal-efect yang sangat jelas karena exposure sudah ditentukan terlebih dahulu dan penelitian dilakukan dalam rentang waktu yang lumayan lama. Sedangkan pada penelitian ini menggunakan metode cross-sectional sehingga tidak bisa menentukan hubungan causal-effect karena data diambil dalam waktu yang bersamaan. Disamping itu pada penelitian ini juga tidak memuat data mengenai berat ringannya penyakit pre operasi seperti pada penelitian di Taiwan, seperti yang diketahui berat ringan suatu penyakit mempengaruhi penyembuhan luka dari pasien.

Selain dengan kadar albumin, sejumlah studi juga mengungkapkan hubungan status gizi dengan penyembuhan luka. Pada penelitian yang dilakukan oleh Syahrul,dkk. (2016), ditemukan bahwa penyembuhan luka pasca pembedahan berhubungan secara bermakna dengan status gizi pasien berdasarkan Indeks Masa Tubuh (IMT) dan kadar albumin pasien. Hasil penelitian yang sama juga dilaporkan oleh Ija \& Mahmudi (2009), ditemukan bahwa pasien yang telah mengalami malnutrisi sebelum pembedahan berisiko 4,8 kali lebih besar mengalami penyembuhan luka yang tidak baik, dan berisiko 5,5 kali lebih besar mengalami rawat inap 7 hari lebih lama dari pasien yang bergizi normal. ${ }^{5}$

Perbedaan penelitian ini dengan penelitian oleh Syahrul,dkk. (2016) yaitu pada penelitian ini tidak memuat data mengenai status nutrisi pre operatif pasien padahal status nutrisi erat kaitannya dengan kadar albumin dan penyembuhan luka. Selain itu pada penelitian ini juga tidak memuat berat ringannya pembedahan yang dijalani pasien, diketahui berat ringannya pembedahan mempengaruhi status nutrisi pasien. Pada penelitian ini juga tidak memuat mengenai IMT dan Basal Metabolic Rate (BMR) pasien dimana IMT dan BMR merupakan indikator pengukuran status nutrisi.

Studi lain yang melibatkan banyak subyek pada penelitiannya adalah studi di Inggris yang berjudul "Are Albumin Levels a Good Predictor of Mortality in Elderly Patients with Neck of Femur Fractures?" yang menghubungkan kadar albumin dengan mortalitas pasien. Merupakan suatu penelitian retrospektif, longitudinal, observasional. Karakteristik subyek penelitian yaitu awalnya diperoleh 496 pasien. Dua puluh lima pasien dikeluarkan dengan alasan tidak ada operasi dilakukan, hanya 471 pasien yang dapat digunakan: 142 pria $(30,2 \%)$ dan 329 wanita $(69,8 \%)$. Tingkat albumin pra-operasi secara signifikan terkait dengan kelangsungan hidup (rasio hazard 0,957: 95\% CI $(0,937,0,978) ; \mathrm{p}<0,001)$. Dengan demikian, pengurangan $1 \mathrm{~g} / \mathrm{dL}$ dalam albumin pra-operasi dikaitkan dengan peningkatan bahaya kematian 4,3\%. Di antara 152 pasien yang tingkat albumin pra-operasinya dikategorikan normal, 51 pasien $(33,6 \%)$ meninggal selama studi. Di antara 240 pasien yang pratingkat albumin operatif dikategorikan sebagai rendah ringan, 134 pasien (55,8\%) meninggal selama programpembelajaran. Di antara 79 pasien yang tingkat albumin pra-operasinya dikategorikan sebagai rendah sedang / berat, 54 pasien $(68,4 \%)$ meninggal selama penelitian. ${ }^{9}$

Penelitian ini juga didukung oleh hasil penelitian yang dilakukan oleh Agung \& Hendri (2005), yang meneliti tentang "Pengaruh Kadar Albumin Serum terhadap Lamanya Penyembuhan Luka Operasi di Bagian Bedah Digestive RS Dr. Sardjito Yogyakarta". responden yang diobservasi sembuh luka adalah 29 (47,54 \%) pasien sembuh primer pada hari ketujuh dan $32(52,46 \%)$ pasien dinyatakan sembuh tetapi lebih dari 7 hari. Tidak ada satupun pasien yang tereksklusi karena terjadi luka infeksi luka operasi. Kesimpulan dari penelitiannya adalah hipoalbumin masih dapat ditemukan pada pasien yang masuk RS Dr, Sardjito dan terdapat hubungan yang bermakna secara statistik antara kadar albumin serum dengan lamanya penyembuhan luka. Menurut Agung \& Hendri (2015) penyembuhan luka melalui suatu tahapan tertentu untuk mencapai kondisi seperti sebelum terjadinya luka. Proses penyembuhan luka ini memerlukan protein sebagai dasar untuk terjadinya jaringan kolagen, sedangkan komponen penting dari protein ialah albumin. ${ }^{10}$ 
Hasil penelitian ini tidak sesuai dengan penelitian yang dilakukan di Surabaya yang berjudul "Evaluasi Penggunaan Albumin Pada Pasien Luka Bakar Di Rsud Dr. Soetomo" yang merupakan penelitian obervasional deskriptif retrospektif, dimana dari 26 pasien luka bakar yang menerima terapi albumin, pasien laki-laki $(69,2 \%)$ dan perempuan (30,8\%), serta umur dengan pasien terbanyak adalah 20 sampai 59 tahun (76,9\%). Albumin yang digunakan albumin $20 \% 100 \mathrm{~mL}$ dengan dosis 20 gram dan diberikan secara infusi drip. Kenaikan kadar albumin rata-rata adalah $0,83 \mathrm{~g} / \mathrm{dL}$. Selain peningkatan, terdapat pula beberapa pasien yang justru mengalami penurunan kadar albumin setelah pemberian terapi. Dari 26 pasien, terdapat 12 pasien yang mengalami rata-rata penurunan sebesar 0,68 g/dL. Hanya 17 pasien yang bertahan hidup sedangkan 9 pasien tetap meninggal meskipun telah diberikan terapi albumin. ${ }^{11} \mathrm{Hal}$ ini berbanding terbalik dengan hail penelitian lain yang menyatakan semakin baik kadar atau normal kadar albumin yang dimilki pasien semakin baik tingkat kesembuhan luka pasien. ${ }^{12}$ Terjadinya penurunan kadar albumin setelah pemberian cairan albumin pada penelitian oleh Soetomo (2016) disebabkan oleh beberapa faktor diantaranya yaitu kondisi klinis dari setiap pasien luka bakar. Luas area bakar sangat mempengaruhi ketahanan kadar albumin pada tubuh pasien. Semakin luas bagian tubuh yang terbakar, maka akan semakin besar kemungkinan terjadinya ekstravasasi cairan atau hilangnya kandungan protein plasma seperti albumin, air, dan elektrolit dari tubuh. ${ }^{11}$

\section{KETERBATASAN}

Penelitian ini dilakukan dengan menggunakan desain potong lintang (cross-sectional) sehingga hasil penelitiannya terbatas untuk menguji hubungan antara kadar albumin dengan penyembuhan luka pada pasien pasca bedah. Penelitian ini tidak melakukan pengukuran kadar albumin secara serial dan kadar albumin pasca operasi. Harusnya kadar albumin diukur setiap hari hingga menjelang operasi agar tidak menunjukkan hasil albumin palsu namun dalam data rekam medis rata-rata pasien dilakukan pengukuran albumin hanya sekali dikarenakan jarak waktu yang pendek antara pasien masuk rumah sakit dengan dilakukannya operasi.

\section{SIMPULAN}

Terdapat hubungan yang bermakna antara kadar albumin dan penyembuhan luka pada pasien pasca bedah di RSUP Sanglah. Pasien pasca bedah yang memilki kadar albumin tidak normal 5,1 kali lebih banyak mengalami luka tidak sembuh dibandingkan dengan pasien yang memilki kadar albumin normal.

Diharapkan dapat dilakukan penelitian serupa dengan desain penelitian cohort dan menggunakan data parametrik sehingga dapat diketahui bagaimana nilai prognostic dan efek klinis yang lebih konkret atas penilaian kadar albumin dengan penyembuhan luka.

\section{KONFLIK KEPENTINGAN}

Penulis menyatakan tidak terdapat suatu konflik kepentingan terhadap publikasi dari artikel ini.

\section{PENDANAAN}

Penelitian ini tidak mendapatkan suatu pendanaan yang diberikan oleh pemerintah ataupun lembaga swasta lainnya.

\section{KONTRIBUSI PENULIS}

Konsep penelitian: Ni Luh Gede Apsari Pararesthi, Kadek Agus Heryana Putra, Putu Kurniyanta. Pengumpulan data, input data dan pengolahan data: Ni Luh Gede Apsari Pararesthi. Penyusunan naskah Penelitian: Ni Luh Gede Apsari Pararesthi.

\section{ETHICAL CLEARANCE NUMBER}

\author{
2129/UN14.2.2.VII.14/LP/2018.
}

\section{DAFTAR PUSTAKA}

1. Kementerian K. Pembedahan Tanggulangi 11\% Penyakit di Dunia. 2015.[online] Available at: http://www.depkes. go.id/article/print/pembedahan-tanggulangi-11penyakit-di-dunia.html. [diunduh : 20 Oktober 2017]

2. Rampengan SFY., Rondonuwu R. \& Onibala F. Pengaruh Teknik Relaksasi Dan Teknik Distraksi Terhadap Perubahan Intensitas Nyeri Pada Pasien Post Operasi Di Ruang Irina A Atas Rsup Prof. Dr. R. D. Kandou Manado. 2014. 5, p.2.

3. Diahpradnya OPP., Niryana I., Anda Tusta AP. Karakteristik kanker payudara usia muda di Subbagian Bedah Onkologi Rumah Sakit Umum Pusat Sanglah tahun 2014-2016. Intisari Sains Medis. 2018. 9(1). DOI: 10.15562/ ism.v9i1.163

4. Hasri ET. et al. Praktik Keselamatan Pasien Bedah di Rumah Sakit Daerah. Jurnal Manajemen Pelayanan Kesehatan. 2012. 15(4), pp.198-202.

5. Syahrul S., Hasanuddin U. \& Syahrul S. Hubungan IMT dan Kadar Albumin berhubungan dengan Penyembuhan Luka. 2016. 4, pp.60-69.

6. Murtutik L. \& Suwarni A. Hubungan Kadar Albumin Dengan Penyembuhan Luka Pada Pasien Post Operasi Laparatomy Di Ruang Mawar Rumah Sakit Slamet Riyadi Surakarta. 2013. pp.80-97.

7. Imelda APA. Arniyanti S. Hubungan Kadar Albumin Dengan Penyembuhan Luka Pasien Post Operasi Laparatomi Di Ruang Rawat Inap Rumah Sakit Tk II Pelamonia Makassar. 2014. 
8. Tsai M. et al. 'Clinical impact of albumin in advanced head and neck cancer patients with free flap reconstruction - a retrospective study'. 2018. pp. 1-12. doi: 10.7717/ peerj. 4490.

9. Harrison SJ. et al. 'Are Albumin Levels A Good Predictor Of Mortality In Elderly Patients With Neck Of Femur Fractures?.' 2017. 21(6), pp. 699-704.

10. Agung M., Hendri W. Pengaruh Kadar Albumin Serum terhadap Lamanya Penyembuhan Luka Operasi. 2015. Available at: http://www. dexamedia.com/ test/htdocs/ dexamedicca/article_files/kadar albumin serum_terhadap lamanya_penyenbuhan_luka_operasi.pdf. [diunduh: 07 Desember 2018

11. Soetomo DIR. 'Evaluasi Penggunaan Albumin Pada Pasien Luka Bakar di RSUD Dr. Soetomo', pp. 92-98. 2016. Available at: http://ikatanapotekerindonesia.net/ uploads/rakernasdocs/prosiding/OFK-12.pdf. [diunduh : 11 Desember 2018]
12. Murtutik L. \& Suwarni A., Hubungan Kadar Albumin Dengan Penyembuhan Luka Pada Pasien Post Operasi Laparatomy Di Ruang Mawar Rumah Sakit Slamet Riyadi Surakarta. 2013. pp.80-97.

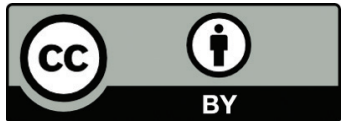

This work is licensed under a Creative Commons Attribution 